\title{
The Impact of the Enrollment Zoning System on the Learning Quality of General Secondary Schools in Special Region of Yogyakarta
}

\author{
Samsul Hadi ${ }^{1},{ }^{*}$ Giri Wiyono ${ }^{1}$, Abdul Rahim ${ }^{2}$ \\ ${ }^{1}$ Department of Electrical Engineering Education, Universitas Negeri Yogyakarta, Indonesia \\ ${ }^{2}$ Department of Educational Research and Evaluation, Universitas Negeri Yogyakarta, Indonesia \\ * Corresponding author. Email: samsul_hd@uny.ac.id
}

\begin{abstract}
There are several problems in the field of education in Indonesia. Some of them are: lack of equity distribution of education, facilities in schools that differ from one school to another, the number of students who is not balanced between one school to another, and parents who complain that their children go to school near their home. This study aims to determine the effect of the enrollment zoning system policy on the quality of general secondary schools in the Special Region of Yogyakarta. This research was conducted with a descriptive research approach. The subjects of this study were 12 principals and 60 teachers of general secondary schools in the Special Region of Yogyakarta. The respondents were selected using purposive non probability sampling technique based on district area, school status, and school accreditation category. The instrument used in this study consisted of four aspects, including: school organization and governance, learning quality, student competence, and teaching competence. The coefficients of the questionnaire validity test results for each aspect were known as 0.81 to $0.92,0.77$ to $0.90,0.71$ to 0.92 , and 0.67 to 0.82 , respectively; while the reliability coefficients were $0.97,0.93,0.90$ and 0.80 respectively. The results of multivariate analysis of variance approach showed that aspects of school organization and governance in Yogyakarta are higher than other districts. The aspect of student competence in Gunung Kidul district is higher than other districts, and aspect of teaching competence in Kulonprogo district is higher than other districts. While for the aspect of learning quality, there is no significant difference in terms of the district/city area.
\end{abstract}

Keywords: Educational quality, Enrollment zoning system, General secendary school

\section{INTRODUCTION}

In the digital era 4.0 , the existence of quality human resources is very important [1], [2]. The world of education plays a very important and strategic role in preparing quality human resources [3], [4]. Education is currently faced with increasingly sophisticated demands for goals, increasing both variety and quality [5], [6]. In the current era of globalization, education in Indonesia is faced with enormous challenges [7], [8] which is characterized by quality competition requires all parties in various fields and development sectors to continuously improve their competence [9]. This makes it important that efforts to improve the quality of education both quantitatively and qualitatively must be carried out continuously, so that education can be used as a vehicle in building the character of the nation [10].
Education quality assurance has an important role in developing the quality of all education systems internally and externally [11]. The quality of education in the sociological approach is seen as an effort to improve students' competencies and skills needed in further educational careers or successfully entering the labor market [12], [13] through a quality process by checking and maintaining the quality of the education system [14]. In addition, the quality of education is the ability of the education system, both in terms of management and in terms of the educational process, which is directed effectively to increase added value and input factors in order to produce the highest output [15].

The world of education plays a very important and strategic role in preparing quality human resources [16] In improving the competitiveness of human resources so 
that they can compete in the global world, namely improving the quality of education. According [17] In general, to improve the quality of education, it is necessary to start with a strategy to increase the distribution of education in macro and micro elements. Equitable distribution of education on a micro scale in an area is one solution in improving the quality of education in that area [18]. Equitable education is supported by the state's contribution in improving the quality and equality of education [19-20]. This shows that good quality education does not only give birth to a generation of cognitive domains but also generations who have good behavior, are skilled and creative [21].

Currently, the distribution of education in the regions is still a quality gap with the quality of education being unequal in each region. To solve this problem, efforts need to be made to improve the quality of education in various aspects, and equal distribution of education in every region in Indonesia [22-24]. An alternative solution offered by the government is the application of a zoning system for new student admissions (PPDB). Zoning system provisions PPDB year 2020 based on [25] which aims to ensure the acceptance of new students in an objective, accountable, transparent and nondiscriminatory manner so as to encourage increased and equitable access to education services. The zoning system is a new student admission policy (PPDB) This is done by determining the zone radius between the school and the place where the student is domiciled.

The relevance of this research is research conducted by [26] on the Policy Analysis of the Zoning System on the Behavior of Junior High School Students in Yogyakarta. Another research conducted by [27] Understanding the Dichotomy and Dualism of Education in Indonesia. Furthermore, the research was carried out by [28] about the Effectiveness of New Student Admission (PPDB) Using the Zoning System in Equity and Improving the Quality of Education (A Case Study at a State Junior High School in Temanggung District). In addition, research was carried out by [29] on the Zoning Program in Elementary Schools as an Effort to Equalize the Quality of Education in Indonesia. The purpose of this study was to determine the quality of education in the Special Region of Yogyakarta (DIY) after the implementation of the zoning system PPDB policy, Furthermore, this study wants to know the quality of education in districts/cities in DIY after the implementation of the PPDB zoning system policy.

\section{METHOD}

This research used a survey method. This research was conducted with a quantitative research approach. The population of this study were principals and teachers in Senior high school (SMA). The research samples consisted of 15 principals and 54 teachers from 15 senior high schools spread over five different districts in the Special Region of Yogyakarta (DIY), Indonesia. Sampling was carried out using a stratified random sampling technique by taking into account several levels, namely Regency (Yogyakarta city, Sleman, Bantul, Kulonprogo, and Gunung Kidul), state school status, and accreditation category (achievement, very good, and good). This technique aims to ensure that the sample obtained will be evenly distributed at all levels and represent all elements of a heterogeneous population. The instrument used in this study is a questionnaire consisting of four aspects, namely school organization and governance, quality of learning, student competence, and teaching competence.

Measurement results in quantitative research were analyzed using descriptive statistics and the average difference between study sample areas were tested using Multivariate Analysis of Variance. This analysis is used to measure the effect of the independent variable (district area) with a categorical scale on several dependent variables (quality of education) with a quantitative data scale at the same time. Qualitative data analysis was carried out by following the procedures [30] with stages covering data collection, data reduction, data presentation, and drawing conclusions.

\section{RESULT AND DISCUSSION}

\subsection{Overview of the Quality of Education in General Secondary Schools}

Data on the quality of education is obtained from Senior High School in the Special Region of Yogyakarta. The results of the analysis of the quality of education in the Special Region of Yogyakarta obtained from the four aspects can be seen in Figure 1.

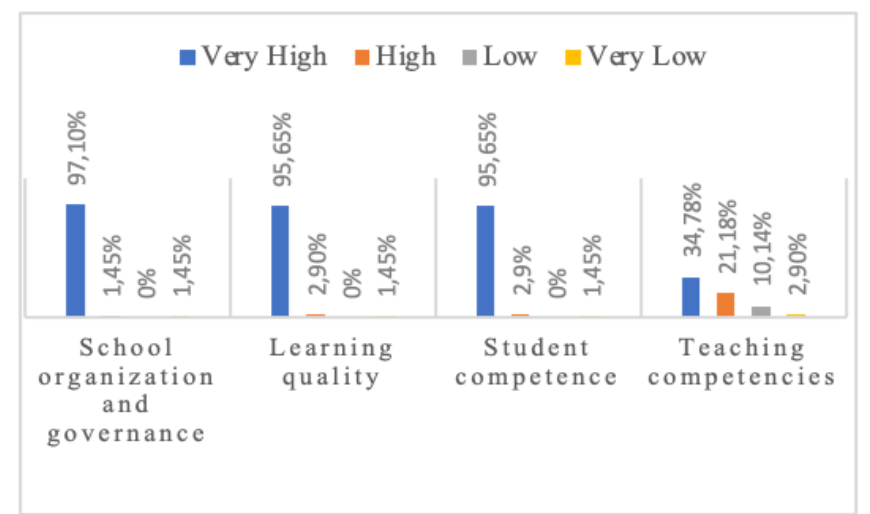

Figure 1. Quality of education Senior High School in the Special Region of Yogyakarta.

Based on the data in Figure 1, it is obtained that aspects of school organization and governance are categorized as very high at $97.1 \%$, high at $1.45 \%$, low at $0 \%$, and very low at $1.45 \%$. Aspects of the quality of learning and competence of students in the very high category of $95.65 \%$, high $2.9 \%$, low $0 \%$, and very low $1.45 \%$. Aspects of teaching competence in the very high category of $34.78 \%$, high $52.18 \%$, low $10.14 \%$, and very low $2.9 \%$. Overall the quality of education in Senior High School in the Special Region of Yogyakarta is in the very high category. 


\subsection{Quality of education for each district or city School in the Special Region of Yogyakarta}

The results of the descriptive analysis of the quality of education Senior High School in the Special Region of Yogyakarta in five districts were obtained as shown in Table 1, includes the integration average of each aspect of the quality of education for each region. Data on the overall quality of education is shown in Figure 2. From the five regions, the quality of education is not much different. The quality of education with the highest average score is in Yogyakarta City and the lowest is in Bantul Regency, while the highest quality of education in aspects of school organization and governance is in the very good category and the lowest is in the aspect of teaching competence which is in the good category.

Table 1. Descriptive statistics on the quality of education in terms of region

\begin{tabular}{|l|l|l|l|l|l|}
\hline District & N & \multicolumn{3}{|l|}{$\begin{array}{l}\text { Quality of High School education in } \\
\text { Yogyakarta }\end{array}$} \\
\cline { 3 - 6 } & & $\begin{array}{l}\text { Lowest } \\
\text { Score }\end{array}$ & $\begin{array}{l}\text { Highest } \\
\text { Score }\end{array}$ & Mean & $\begin{array}{l}\text { Standar } \\
\text { deviatio } \\
n\end{array}$ \\
\hline Yogyakarta & 14 & 12 & 40 & 23.63 & 9.04 \\
\hline Sleman & 14 & 14 & 40 & 23.57 & 8.63 \\
\hline $\begin{array}{l}\text { Gunung } \\
\text { Kidul }\end{array}$ & 14 & 13 & 40 & 23.52 & 8.80 \\
\hline Bantul & 14 & 9 & 40 & 21.48 & 8.74 \\
\hline Kulonprogo & 13 & 15 & 40 & 24.00 & 8.31 \\
\hline Total & 69 & 9 & 40 & 23.23 & 8.70 \\
\hline
\end{tabular}

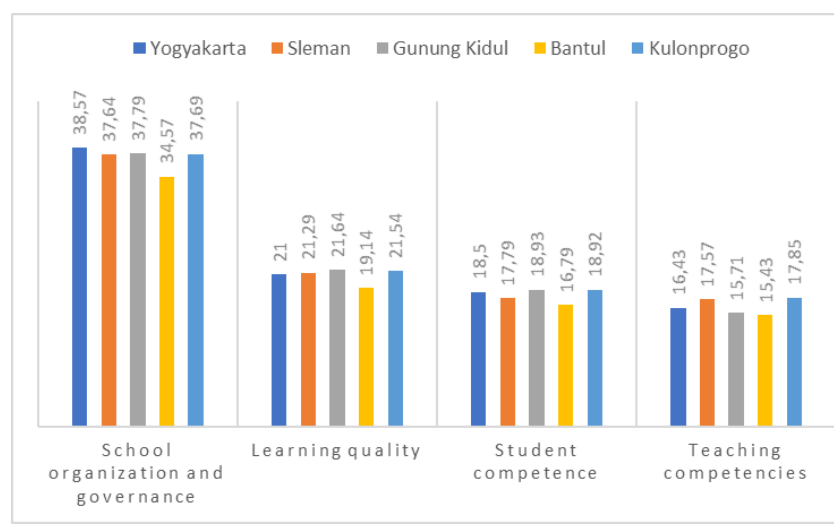

Figure 2. The average value of each aspect of the quality of education in each region and its total.

\subsection{Multivariate Analysis of Variance Normality test}

The assumption of the dependent variable with multivariate normal distribution is illustrated by the scatter-plot correlation between the Mahalanobis
Distance variable from the quality value variable and the qi variable (chi square value) as shown in Figure 3. The correlation coefficient obtained is 0.880 which indicates a very high correlation coefficient, so it can be concluded that the data are normally distributed multivariate [31].

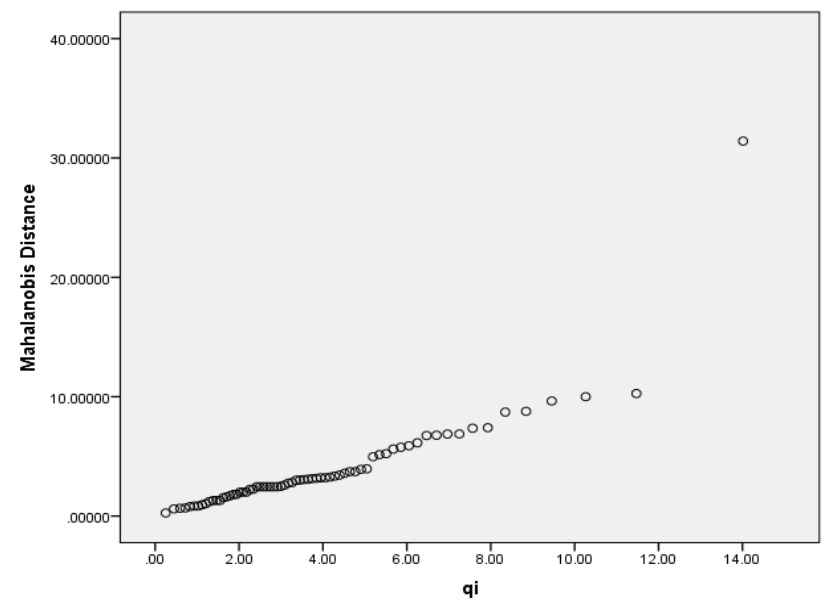

Figure 3 Scatter-plot of correlation between mahalanobis distance variable and qi variable

\subsubsection{Homogeneity test}

The Box's Test simultaneously tested the covariance equation between variables showing that the covariance between variables was not equivalent. Levene's Test tests the equality of the variances in any given variable, showing that the variances in each variable are unequal. However, the homogeneity test is not an absolute prerequisite test for using ANOVA. This test adds information about the results of data analysis and considerations in conducting Post-Hoc testing using Games-Howell [31].

\subsubsection{Simultaneous multivariate analysis of variance}

The results of simultaneous multivariate analysis of variance can be seen in Table 2 .

Table 2. Result of multivariate analysis of variance

\begin{tabular}{|l|l|l|l|l|}
\hline & Effect & S & $\begin{array}{l}\text { Partial Eta } \\
\text { Squared }\end{array}$ \\
\hline Intercept & Pillai's Trace & 1930.343 & .000 & .992 \\
\hline & Wilks's Lambda & 1930.343 & .000 & .992 \\
\hline & Hotelling's Trace & 1930.343 & .000 & .992 \\
\hline & Roy's Largest Root & 1930.343 & .000 & .992 \\
\hline Districts & Pillai's Trace & 2.290 & .004 & .125 \\
\hline & Wilks's Lambda & 2.299 & .004 & .128 \\
\hline & Hotelling's Trace & 2.246 & .005 & .131 \\
\hline & Roy's Largest Root & 4.661 & .002 & .226 \\
\hline
\end{tabular}

Based on Table 2, the simultaneous comparison test obtained p-value $<0.05$, this indicates that at the $95 \%$ confidence level there are significant differences in the 
four aspects of the quality of education when viewed from the district or city.

\subsection{Partial multivariate analysis of variance}

The results of the partial multivariate analysis of variance can be seen in Table 3 .

Table 3. Result of Tests Of Between-Subjects Effects

\begin{tabular}{|l|l|l|l|l|}
\hline Sources & $\begin{array}{l}\text { Dependent } \\
\text { variable }\end{array}$ & F & Sig & $\begin{array}{l}\text { Partial Eta } \\
\text { Squared }\end{array}$ \\
\hline Districts & $\begin{array}{l}\text { School } \\
\text { organization } \\
\text { and } \\
\text { governance }\end{array}$ & 2.723 & .037 & .145 \\
\hline & $\begin{array}{l}\text { Learning } \\
\text { quality }\end{array}$ & 2.368 & .062 & .129 \\
\hline $\begin{array}{l}\text { Student } \\
\text { competence }\end{array}$ & 2.843 & .031 & .151 \\
\hline $\begin{array}{l}\text { Teaching } \\
\text { competencies }\end{array}$ & 3.231 & .018 & .168 \\
\hline
\end{tabular}

Based on Table 3, the partial comparison test was obtained in aspect school organization and governance, aspect student competence, and aspect teaching competencies, obtained $p$-value $<0.05$, this indicates that at the $95 \%$ confidence level there are significant differences in the three aspects of the quality of education when viewed from the district or city. While aspect leaning quality obtained p-value $>0.05$ so it can be concluded that there is no significant difference in aspect 2 seen from the district or city.

\subsection{Post-Hoc test with Games-Howell approach}

Based on the Games-Howell test, the integrated quality of education in the city of Yogyakarta in terms of organization and school governance is higher than in other districts. The integrated quality of education in Gunung Kidul district on student competence is higher than other districts. The integrated quality of education in Kulonprogo district in teaching competence is higher than other districts. This shows that of the three aspects that have the highest differences, respectively, they are in the city of Yogyakarta, Gunung Kidul Regency, and Kulonprogo Regency. Meanwhile, in the aspect of learning quality, there are no differences in the five regencies or cities in the Special Region of Yogyakarta.

\subsection{Discussion}

Quality of education is the implementation of education in an institution, to the extent that education at the institution has achieved success [32]. The quality of education according to the ability of educational institutions to utilize educational resources to improve learning abilities as optimally as possible [33]. This research uses a questionnaire instrument to determine the quality of education in the Special Region of Yogyakarta. Based on the research, the quality of education consists of four aspects, namely school organization and governance, learning quality, student competence, and teaching competence. The coefficients of the questionnaire validity test results for each aspect are known to be 0.81 to $0.92,0.77$ to $0.90,0.71$ to 0.92 , and 0.67 to 0.82 , respectively; while the reliability coefficients are $0.97,0.93,0.90$ and 0.80 , respectively.

Based on the results of the analysis of the quality of education in the Special Region of Yogyakarta as a whole is in the very high category. Data on the overall quality of education from the five districts or cities in the Special Region of Yogyakarta, the quality of education is not much different. The quality of education with the highest average score is in Yogyakarta City and the lowest is in Bantul Regency, while the highest quality of education in aspects of school organization and governance is in the very good category and the lowest is in the aspect of teaching competence which is in the good category.

The Manova test was conducted to determine differences in the quality of education in five districts or cities in the Special Region of Yogyakarta. The classical assumption of normality test obtained data with normal distribution and homogeneity test obtained inhomogeneous data, but the homogeneity test was not an absolute prerequisite test for using ANOVA. This test adds information about the results of data analysis and considerations in conducting Post-Hoc testing using Games-Howell (Johnson \& Wichern, 2007). Based on the multivariate analysis of variance test, it was concluded that there was a simultaneous influence on the quality of education in terms of districts or cities in the Special Region of Yogyakarta. Tests of BetweenSubjects Effects are used to determine the partial differences of the four aspects of education quality in terms of region. The results of the Tests of BetweenSubjects Effects concluded that in aspects of school organization and governance, student competence, and teaching competence, there were significant differences in the three aspects of the quality of education when viewed from the district/city area. While in the aspect of learning quality, there is no significant difference in this aspect in terms of the district or city area.

Post-Hoc test with the Games-Howell test approach, the integrated quality of education in the city of Yogyakarta in the aspects of organization and school governance is higher than other districts. The integrated quality of education in Gunung Kidul district on student competence is higher than other districts. The integrated quality of education in Kulonprogo district in teaching competence is higher than other districts. This shows that the three aspects that have the highest differences, respectively, they are in the city of Yogyakarta, Gunung Kidul Regency, and Kulonprogo Regency.

\section{CONCLUSION}

This study concludes that there are differences in the quality of education at the vocational high school level in each district in the Special Region of Yogyakarta. In general, the high school level in each region in the Special Region is included in the very high category for all aspects. In addition, based on the MANOVA test, the 
quality of education in the city of Yogyakarta- in terms of organization and school governance is higher than in other districts. The quality of education in Gunung Kidul district- in terms of student competence is higher than in other districts. The quality of education in Kulonprogo district- in terms of teaching competence is higher than in other districts. Concerning the aspect of learning qualitythere is no significant difference in this aspect in terms of the district/city area.

\section{ACKNOWLEDGMENT}

The authors would like to thank Yogyakarta State University for providing research grants for the completion of this study.

\section{REFERENCES}

[1] E. B. Wibowo, T. Legionosuko, and J. Mahroza, "Industry 4.0: Challenges and opportunities in competency development for defense apparatus' human resources," Int. J. Adv. Sci. Technol., vol. 29, no. 7, pp. 45-60, 2020.

[2] J. Vrchota, M. Mařiková, P. Řehoř, L. Rolínek, and R. Toušek, "Human resources readiness for industry 4.0," J. Open Innov. Technol. Mark. Complex., vol. 6, no. 1, pp. 1-20, 2020, DOI: 10.3390/joitmc6010003

[3] S. Masino and M. Niño-Zarazúa, "What works to improve the quality of student learning in developing countries?," Int. J. Educ. Dev., vol. 48, pp. 53-65, 2016, DOI: 10.1016/j.ijedudev.2015.11.012.

[4] A. M. Aleixo, S. Leal, and U. M. Azeiteiro, "Conceptualization of sustainable higher education institutions, roles, barriers, and challenges for sustainability: An exploratory study in Portugal," J. Clean. Prod., vol. 172, pp. 1664-1673, 2018,

DOI:

[5] P. Serdyukov, "Innovation in education: what works, what doesn't, and what to do about it?," J. Res. Innov. Teach. Learn., vol. 10, no. 1, pp. 4-33, 2017, DOI: 10.1108/jrit-10-2016-0007.

[6] T. Schulze-Cleven and J. R. Olson, "Worlds of higher education transformed: toward varieties of academic capitalism," High. Educ., vol. 73, no. 6, pp. 813-831, 2017, DOI: 10.1007/s10734017-0123-3

[7] D. Jamaluddin, "Character Education In Islamic Perspective,” Int. J. Sci. Technol. Res., vol. 2, no. 2, pp. 187-189, 2013.

[8] N. D. Guskova, S. M. Vdovin, I. N. Krakovskaya, and Y. Y. Slushkina, "The quality of education as a primary concern of the sustainable development," Eur. Res. Stud. J., vol. 19, no. 3, pp. 239-257, 2016, DOI: 10.35808/ersj/574

[9] A. Ahyanuardi, O. Candra, D. T. P. Yanto, and A. A. A. Bata, "The Development of 1 Phase
Induction Motor Training Kits," Int. J. Sci. Technol. Res., vol. 9, no. 08, pp. 541-545, 2020.

[10] E. Mulyasa, Standar Kompetensi Sertifikasi Guru. Bandung: PT Remaja Rosdakarya Offset, 2007.

[11] A. Mursidi and Soeharto, "An Introduction: Evaluation Of Quality Assurance For Higher Educational Institutions Using Rasch Model," vol. 1, no. 1, pp. 1-6, 2016.

[12] J. Scheerens, H. Luyten, and J. van Revans, Perspective on educational quality: Illustrative outcomes on primary and secondary schooling in the Netherlands. Dordrecht: Springer US, 2011.

[13] M. R. Spruit and T. Adriana, "Quantifying Education Quality in Secondary Schools," Int. J. Knowl. Soc. Res., vol. 6, no. 1, pp. 55-86, 2015, DOI: 10.4018/ijksr.2015010104.

[14] A. K. Agnihotri, "Quality in Primary and Secondary Education," Sch. Res. Journal's, vol. 4, pp. 4878-4884, 2016.

[15] M. Abdullah, "Manajemen Mutu Pendidikan Di Sekolah Peran Kepemimpinan Kepala Sekolah, Profesionalisme Guru, Dan Partisipasi Masyarakat Dalam Peningkatan Mutu Pendidikan Di Sekolah," J. Penelit. Pendidik., vol. 17, no. 3, pp. 190-198, 2018, DOI 10.17509/jpp.v17i3.9612.

[16] F. Hénard and D. Roseveare, Fostering Quality Teaching in Higher Education: Policies and Practices, no. September. 2012.

[17] M. Saifulloh, Z. Muhibbin, and H. Hermanto, "Strategi Peningkatan Mutu Pendidikan Di Sekolah," J. Sos. Hum., vol. 5, no. 2, pp. 206218, 2012, DOI: 10.12962/j24433527.v5i2.619.

[18] C. Lewis, "What Is Improvement Science? Do We Need It in Education?," Educ. Res., vol. 44, no. 1, pp. 54-61, 2015, DOI: 10.3102/0013189X15570388.

[19] F. T. Pfeffer, "Equality and quality in education. A comparative study of 19 countries," Soc. Sci. Res., vol. 51, pp. 350-368, 2015, DOI: 10.1016/j.ssresearch.2014.09.004.

[20] K. Leithwood, A. Harris, and D. Hopkins, "Seven strong claims about successful school leadership revisited," Sch. Leadersh. Manag., vol. 40, no. 1, pp. 5-22, 2020, DOI: 10.1080/13632434.2019.1596077

[21] J. Warlizasusi, "Reformasi Pendidikan Dalam Rangka Peningkatan Mutu Pendidikan di Kabupaten Rejang Lebong," Tadbir J. Stud. Manaj. Pendidik., vol. 1, no. 2, p. 125, 2017, DOI: $10.29240 /$ jsmp.v1i2.243.

[22] M. Idrus, "Mutu Pendidikan Dan Pemerataan Pendidikan Di Daerah Quality Of Education And Regional Educational Equity," Psikopedagogia, vol. 1, no. 2, 2012.

[23] Zurqoni, H. Retnawati, J. Arlinwibowo, and E. Apino, "Strategy and implementation of character education in senior high schools and 
vocational high schools," J. Soc. Stud. Educ. Res., vol. 9, no. 3, pp. 370-397, 2018, DOI: 10.17499/jsser.01008.

[24] E. Gindo, C. Anagaw, and S. Sapo, "Provision of Quality Education in Secondary Schools: Investigation of Factors," Eur. J. Educ. Stud., vol. 7, no. 1, pp. 326-337, 2020, DOI: 10.5281/zenodo. 3880450 .

[25] Kemendikbud, "Peraturan Menteri Pendidikan, dan Kebudayaan Nomor 44 Tahun 2019," Peratur. Menteri Pendidik. dan Kebud., pp. 125, 2019, [Online]. Available: jdih.kemdikbud.go.id.

[26] A. Nurlailiyah, "Analisis Kebijakan Sistem Zonasi Terhadap Perilaku Siswa SMP di Yogyakarta," Realita J. Penelit. Dan Kebud. Islam, vol. 17, no. 1, pp. 13-23, 2019, DOI: https://doi.org/10.30762/realita.v17i1.1381.

[27] E. Kurniyati, "Memahami Dikotomi Dan Dualisme Pendidikan di Indonesia," Rausyan Fikr J. Pemikir. dan Pencerahan, vol. 14, no. 1, pp. 1-19, 2018, Doi: 10.31000/rf.v14i1.669.

[28] H. Setiyanti, "Efektivitas Penerimaan Peserta Didik Baru (PPDB) Menggunakan Sistem Zona Dalam Pemerataan Dan Peningkatan Kualitas Pendidikan (Studi Kasus Pada Smpn Kecamatan Temanggung)," G-Couns J. Bimbing. dan
Konseling, vol. 3, no. 2, pp. 162-171, 2019, doi: 10.31316/g.couns.v3i2.309.

[29] A. A. Safarah and U. B. Wibowo, "Program Zonasi di Sekolah Dasar Sebagai Upaya Pemerataan Kualitas Pendidikan di Indonesia," Lentera Pendidik. J. Ilmu Tarb. dan Kegur., vol. 21, no. 2, p. 206, 2018, DOI: 10.24252/lp.2018v21n2i6.

[30] M. B. Miles and A. M. Huberman, Qualitative data analysis: An expanded sourcebook. New York: Sage publication, 1994.

[31] R. A. Johnson and D. W. Wichern, Applied Multivariate Statistical Analysis. New Jersey: Prentice Hall, 2007.

[32] R. Laurie, Y. Nonoyama-Tarumi, R. Mckeown, and C. Hopkins, "Contributions of Education for Sustainable Development (ESD) to Quality Education: A Synthesis of Research," J. Educ. Sustain. Dev., vol. 10, no. 2, pp. 226-242, 2016, DOI: $10.1177 / 0973408216661442$.

[33] D. Prestiadi, W. Zulkarnain, and R. Bambang Sumarsono, "Visionary Leadership in Total Quality Management: Efforts to Improve the Quality of Education in the Industrial Revolution 4.0," Adv. Soc. Sci. Educ. Humanit. Res., vol. 381, 2020, DOI: 10.2991/coema19.2019.40. 